\title{
YOU ARE CORDIALLY INVITED TO...THE DISTANCED PARTICIPATION IN A ROYAL WEDDING
}

\section{MARLENE HUGOSON}

On 19 June 2010 Swedish Crown Princess Victoria married Mr Daniel Westling. The wedding was celebrated not only in the capital city of Stockholm, but also in the groom's home village, where some 6,000 people assembled to watch and celebrate the wedding beneath a giant television screen placed in a country field. As examples of this type of distanced participation become more noticeable in the ritual year, the phenomenon becomes increasingly interesting to follow. This time the investigation leads to the small village of Ockelbo, Sweden, where the municipality organised a large-scale village feast and consciously rooted the performance in the rural identity of the area. ${ }^{1}$

Keywords: royal wedding, distanced participation, village promotion, Ockelbo
19. junija 2010 se je švedska kronska princesa Viktorija poročila z Danielom Westlingom. Poroke niso praznovali le v švedski prestolnici Stockholmu, marveč tudi v ženinovi domaci vasi, kjer se je okrog 6000 ljudi zbralo k ogledu in praznovanju poroke pred ogromnim televizijskim zaslonom, nameščnim na podeželskem polju. Ker so primeri tovrstne oddaljene udeležbe v okviru ritualnega leta vse pogostejsi, je ta fenomen postal zanimivejsi za opazovanje. Tokrat je preiskava vodila $v$ malo vasico Ockelbo na Švedskem, kjer je mestna občina organizirala obsežno vaško praznovanje in zavestno utemeljila izvedbo v ruralni identiteti področja. Ključne besede: oddaljena udeležba, slavnosti, kraljevska poroka, promocija podeželja, Ockelbo

More than 12,000 people have assembled in Ockelbo to celebrate the wedding between Swedish Crown Princess Victoria and village son Daniel Westling, a man of the people. It should be noted that a mere 6,000 people live in Ockelbo. It is mainly the villagers and their neighbours from the district that have come together for the celebration, but a few participants have travelled from other parts of the country to be there while others are part of the media posse deployed to cover the event. Never before has the little village been so much in the public eye as on this day.

1 The material used in this paper is part of a joint documentation of the celebration of the royal wedding, produced by the Department of Dialectology and Folklore Research in Uppsala, Stockholm City Museum, Nordiska museet, and the Royal Armoury in Stockholm. The term 'distanced participation' is my own, building on ideas presented in Eric Hobsbawn's article "Mass-Producing Traditions: Europe 1870-1914" (2005).

2 V tem članku uporabljeni material je del skupne dokumentacije o praznovanju kraljevske poroke, nastal je pod okriljem Oddelka za dialektologijo in folklorne raziskave v Uppsali, stockholmskega Mestnega muzeja, Nordijskega muzeja in Kraljeve heraldike v Stockholmu. Termin »oddaljena udeležba« je moj, utemeljen pa je na idejah, predstavljenih v članku Erica Hobsbawma »Mass-Producing Traditions: Europe 1870-1914«(2005). 
A program filled with local activities has been arranged for the entire wedding week by the Municipality of Ockelbo and is orchestrated by Monica Järnkvist and her team. ${ }^{3}$ The program for the wedding day itself is solid, spanning almost 20 hours. ${ }^{4}$

A large canopy tent has been set up in the manor courtyard at Wij Gardens (a park with show gardens). The tent first functions as a radio broadcast- and breakfast tent, and later in the day as a lunch tent and bubbly bar, serving champagne and beer. Swedish radio and the show Ring så spelar vi (Call and We'll Play It) with host Lisa Syrén entertains the lively radio listeners from seven in the morning onwards. At ten o'clock Melodikrysset (The Melody Crossword) hosted by Anders Eldeman begins, and the listeners on location receive their own crosswords to fill in. Those that wear flowers in their hair are treated to breakfast and, despite the rain, the guests soon begin arriving in large numbers. On a field nearby a stage with a giant television screen has been built for the expected crowds.

\section{DISTANCED PARTICIPATION}

The sun is out again when the wedding ceremony begins in the afternoon. Paper flags are handed out to the viewers on location in Ockelbo and some of them are wearing crowns on their heads. The television cameras allow the viewing public to get closer to the bride and groom than even the guests at the wedding in Stockholm Cathedral, and the interaction with the images on the giant screen is apparent. When the groom's parents Olle and Eva Westling, who live in Ockelbo, are shown on camera the audience of 6,000 cheers, and also when the groom arrives together with the bride's brother, Prince Carl Philip. However, when commentator John Chrispinsson informs the viewers that the groom is from Ockelbo, but places the village in the wrong province, the audience in Ockelbo boos. Oblivious to this, the commentator continues, "It is a piece of, what shall we call it, transformation, magic if you like, that will take place: here Mr Daniel Westling goes into the church. In an hour he will be Prince Daniel, Duke of Västergötland, His Royal Highness, and Knight of the Order of the Seraphim" (SVT 2010b). When Daniel, village son of Ockelbo, is referred to as a prince-to-be, the audience cheers and applauds loudly.

In a close-up shot the audience then get to see the couple exchange rings, whereupon Archbishop Anders Wejryd declares,

You have now entered into holy wedlock with each other... and confirmed this before God and this congregation. You are now husband and wife. May the Lord be with you and guide you in His truth, now and forever (SVT 2010b).

3 Thanks to Monica Järnkvist for hospitality and service shown to two cultural workers doing field work, photographer Jessika Wallin from Nordiska museet and myself. In her report summarising the festivities she also supplies data on the festivities (Järnkvist 2011).

4 In the following I will use historic present tense as a literary handle to give the reader a sense of 'being there'. 


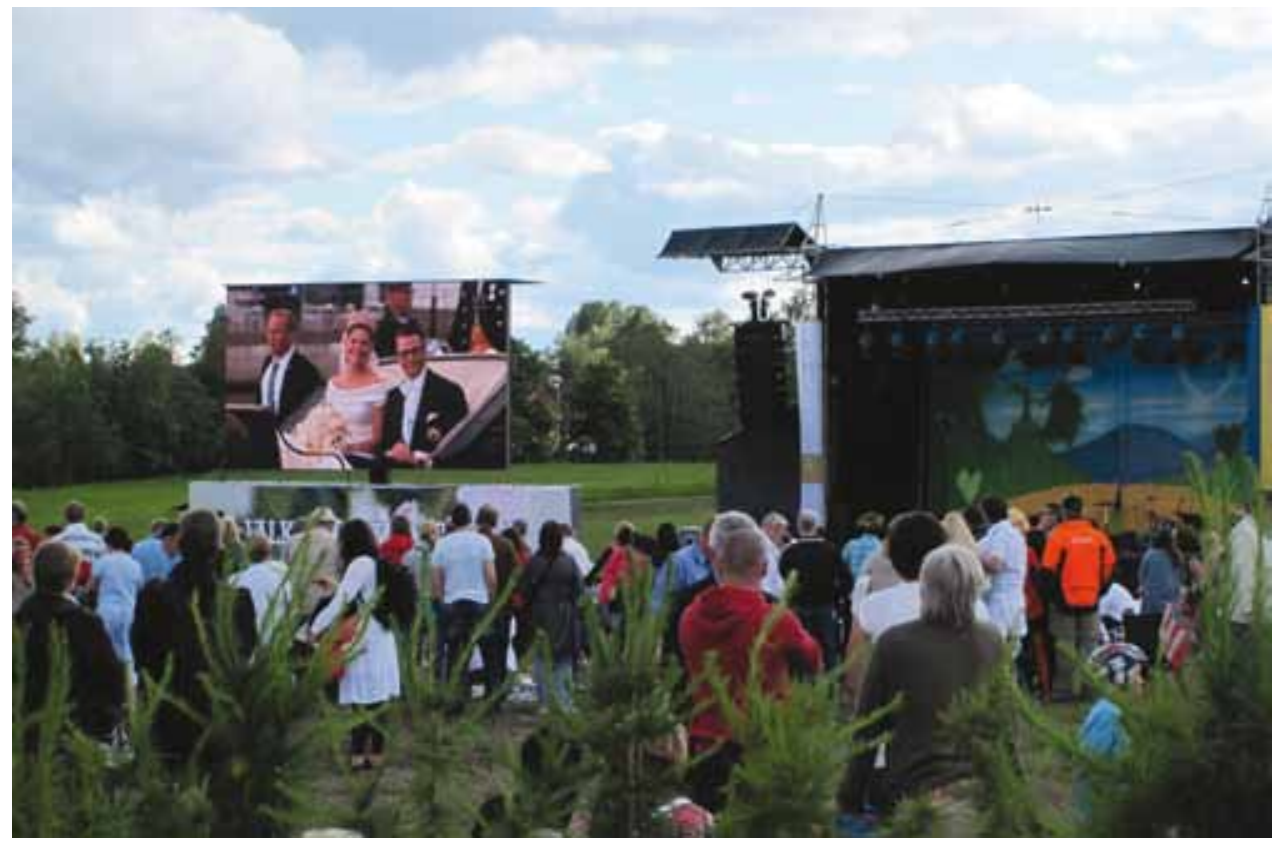

Figure 1. Distanced participation in a Royal wedding. Ockelbo. (Photo: M. Hugoson 2010. (C) Dialekt- och folkminnesarkivet i Uppsala.)

During the pause the archbishop makes, the audience in Ockelbo cheers and applauds again, and when the happy couple pauses on the cathedral steps a moment later, four cheers for them are called from the stage by the chairman of the Municipality of Ockelbo, Magnus Jonsson. The audience joins him and 2,010 yellow balloons are released and sails up from behind the wedding stage towards the blue sky, symbolising both the year and the colours of the Swedish flag. Happy viewers in Ockelbo pop open the wine bottles they have brought and touch glasses to celebrate that the couple have finally been allowed to wed, and they enthusiastically cheer when the bride and groom kiss on the balcony of the royal castle a little while later (SVT 2010a).

\section{NATIONALISTIC ENDEAVOURS}

That Ockelbo opted for such a lavish local celebration of something that takes place in Stockholm, and that a giant television screen becomes such a prominent part of the celebration, can be considered remarkable. However, this is not a unique phenomenon, but rather part of something greater. The distanced participation seen in Ockelbo springs from the same mechanics of rapid social change that brought on the construction of new traditions in the late $19^{\text {th }}$ century, as presented by Eric Hobwbawm in the article "Mass-Producing Traditions: Europe 1870-1914” (Hobsbawm 2005). Technical innovation continue to change 
human interaction, and today computer programs such as Skype allow people to see each other and interact via computer but, despite being a one-way form of communication, the audience in Ockelbo still reacts and interacts with what is happening on the television screen as though it was a two-way form of communication.

The giant television screen in Ockelbo is an excellent example of distanced participation in yearly rituals and life celebrations. Other examples of this are the Nobel festivities arranged around Sweden at the same time as the real Nobel banquet, where the television is part of the festivities so that the guests can toast the King alongside the invited guests at Stockholm City Hall (Hugoson 2007), or the use of television broadcasts and giant television screens during important funerals, allowing those that cannot be fitted into the church to still take part in the ceremony (Hugoson 2011). Looking at broadcast weddings and funerals, it is interesting to note that the outdoor placement of the giant television screens changes the distanced participation, in parts moving it from an indoor setting to a large-scale outdoor production (a phenomenon that can also be seen during the Last Night of the Proms, where people also assemble outdoors in front of giant television screens). ${ }^{5}$

The television broadcasts from the royal wedding is more than entertainment, it also serves a political purpose, as popularisation and consequent strengthening of the monarchy can be identified as part of the nationalistic endeavour at a time of increasing globalization - a globalisation which at times threatens already existing domestic cultural patterns and use of language. In this endeavour the distanced participation plays its part, creating a feeling of community on both the local and the national level. During the celebration in Ockelbo the homogeneity of the crowd is striking, few persons of apparent foreign descent can be spotted, even though Iranians and Somali are two prominent refugee groups in the area. However, the inclusion of multicultural music on the main stage officially signals that immigrants are encouraged to partake in the festivities, following the lead of the Swedish government politics. Yet there is no visible political party behind the municipality's decision to put on a giant village feast including these multicultural ingredients, as opposed to the example shown in István Povedák's paper "Reinvented-invented-copied-traditional-cultural' Festivals in Contemporary Hungary," where the nationalistic political forces behind the festivities were shown to be more prominent (Povedak 2011).

\section{PROXIMITY AND DISTANCE}

The broadcast from the wedding in Stockholm is shown on the giant screen in Ockelbo, but Swedish television, Swedish radio, and several newspapers also sends reports from the celebration in Ockelbo. Swedish radio has several lorries with sound equipment on location for the shows Ring så spelar vi, Melodikrysset, and Sommarkonsert i Ockelbo kyrka (Summer

5 Thanks to Per Vikstrand for enlightening me about Last Night of the Proms. 
Concert in Ockelbo Church). Swedish television covers the celebration in Ockelbo and broadcast shorter segments from the festivities, and reporters from local and national media are on site. The media thus make it possible for the audience watching the broadcasts in Sweden and abroad to take part in the festivities in Ockelbo as well.

The broadcasts and news coverage from Ockelbo to Ockelbo inverted the relationship between proximity and distance; at Bysjöstrand, a retirement home in Ockelbo, the staff arranges a wedding lunch and a cake buffet. Freshly picked flowers decorate the tables, and Swedish flags and yellow and blue balloons decorate the communal areas. Because the eighty elderly persons living at the home cannot partake in the celebrations outside, parts of the celebrations are brought to them: a brass band has been there to perform in the morning, yet their main source of entertainment is the televised broadcasts from Ockelbo. Five groups of elderly people have been seated in front of as many television sets. ${ }^{6}$

\section{DEMOCRATIC DIMENSIONS}

That so many people have assembled in Ockelbo is a sign of both local pride and a testament to the joy felt over the fact that a commoner is allowed to marry the princess, and thus become a prince; it is like something out of a traditional folk legend. Since the end of the 1970s, Swedish parents have joked that their sons and daughters will marry one of the three royal children. The fact that society has now evolved to the point where this is possible, and that love can overcome social obstacles without abdication or loss of titles, gives the wedding a democratic dimension. ${ }^{7}$

Even the Crown Princess herself seems surprised that she has finally been allowed to marry Daniel Westling, after proving the relationship to the world during their eight years as a couple. In the speech she gives from the balcony on the royal castle, she says,

Dear, dear friends, I would like to begin by thanking the Swedish people for giving me my prince. We, my husband and I [strong reaction from the crowd], are so incredibly happy and very thankful that so many want to be here to celebrate with us. It is an enormous experience; this is our greatest day in our lives so far. To feel your support means more to us than you will ever be able to comprehend, it is something incredible. Today is a day we will carry with us in our hearts for the rest of our lives. Thank you. (SVT 2010a).

6 Thanks to division manager Monica Stark for information on the number of elderly at the Bysjöstrand care home and how many groups there were.

7 Only a few generations earlier, three Swedish princes married women from a lower social stratum and consequently lost their titles: Lennart (loss of title in 1932), Sigvard (loss of title in 1934), and Carl Johan (loss of title in 1946). Their relative, British King Edward VIII, was forced to abdicate in 1936 before he could marry Mrs Wallis Simpson. 
A group of women that has been tempted to come to Ockelbo on this day are Elisabet, Anna, Tina, Amalia, Åsa, and Liselotte. They have travelled across the country from Gothenburg to participate in the celebration. To mark the occasion they have dressed up in ball gowns and all but one wears a tiara. By dressing up in fine clothes, jewellery, homemade royal sashes, and giving royal waves, the six friends jestingly assume the obligations of royalty. Because no physical wedding couple is to be found, the six friends thus fill a void and immediately get courted by the media. Their play with class markers can be interpreted as expressing values of equality, but also a contradictory will to emulate the royals because there is no doubt they appreciate the royal family.

\section{OCKELBO AS A BRAND}

After the engagement between the Crown Princess and Daniel Westling was announced the media coverage has been intense, and Ockelbo seized the opportunity to market itself by sending out an invitation to The Great Village Feast, and for a village feast of this dimension much food is required. In the morning 3,000 breakfasts have been served and in the food tents to the left of the manor the preparations have been going on since seven in the morning. The amount of charcoal used is enormous and smoke from the grills drifts like a light fog between the tents. An army of volunteer summer hosts helps out throughout the day, and the activity before lunch is frantic. The "Picnic Royal," the locally produced lunch/ dinner with a luxurious country touch served to those that have bought tickets, consists of small herring pickled in spruce sprouts, wild boar sausages and wild boar steak, hulless oat crème, crisp bread, white-mould cheese, and rhubarb marmalade. By half past three in the afternoon more than 4,000 picnic sets have been served.

Between two and three in the afternoon, a cake buffet is served in a pine walkway planted next to the stubble field with the television screen. A dozen bakers empty a lorry carrying three hundred cakes from the local bakery and place them on a 656-foot-long table, decorated with checkered tablecloths and bouquets of lupines and cow parsley. The bakers then proceed to serve strawberry tart, chocolate- and almond cake, and a white marzipan-covered cake decorated with a plastic gold crown. At each end of the long table a five-tiered wedding cake is placed, decorated with dog roses and daisies. Two thousand tickets have been sold for the buffet and, despite having to eat the cake and drink the coffee in the rain, the paying guests are in a good mood. Several of them resolutely take out their umbrellas when the rain no longer can be ignored.

Aside from the ticket sales for food and beverages, commerce at Wij gardens in Ockelbo is limited. The local industry and local crafts industry ${ }^{8}$ produced by artists and craftsmen is discreetly shown (discreet being the operative word because the people of

8 Thanks to Magnus Gustavsson for the use of the term 'hembygdsindustri' (local crafts industry). 
Ockelbo kept the secret of the romance between the princess and the local lad from the media for several years). Next to the old-fashioned café at Wij Gardens, Mikael Olsson and his son are selling wedding memorabilia and advertising products from a closed-down snowmobile company bearing the name of the village. Inside the café, artist Tony Warren shows a symbol-filled still life titled Tillgivenhet (Affection). It is to be given to the couple from the people of Ockelbo. In honour of the day, seamstress Lena Larsson is dressed in the folk costume of the area, and wears a wreath of buttercups and cow parsley in her hair. She informs me that the bride and groom have just received a pair of folk costumes that she was secretly commissioned to make by the municipality. The second gift from the municipality is a yearly camp for children and youth from low-income areas in the cities. Discreet product placement can be found only in the cutlery tray from Ikea that the "Picnic Royal" is served in, the fleece blankets that the radio audience was able to borrow in the morning, and three small wedding-themed greenhouses that the company has decorated close to the manor buildings.

\section{VILLAGE PROMOTION}

The Municipality of Ockelbo has financed a whole week's worth of entertainment to celebrate the wedding. ' The return on the investment is apparent because the promotional value of the media attention the village receives could never be bought on a municipal budget. It would have been easy for the municipality to sell out and turn the festivities into a money-making extravaganza, but instead there is a sense of occasion and an acute awareness of the level of dignity required by their unexpected connection to the royal house. Kinga Gaspar eloquently uses the phrase "Take the best we have to show who we are," (Gaspar 2011) which could also be used here to sum up how the municipality chose to promote its village - a decision that in turn reflected well on both the village and the groom. ${ }^{10}$

Everything is immaculately planned and the image of Ockelbo that emerges is rural, yet professional: parking and traffic wardens direct the cars to avert chaos on the roads. For the media, with somewhat different needs than the other guests, a press center has been set up inside a traditional wooden house at Wij Gardens and it functions somewhat like the entrance to a hive throughout the day. Reporters set out in search of news segments and then return to forward the information they have gathered to their editorial offices.

9 Thanks to Laurent Sébastien Fournier for pointing out the importance of the municipality's economic involvement in the festivities.

10 In this particular case one will of course never know whether there was a PR specialist working for the royal palace, steering the municipality towards this decision and outcome, or if the restraint shown should be interpreted as an elongation of the previously mentioned discretion, or if it was a combination of the two. 
When the bubbly bar serving alcohol open, a group of hired guards in black uniforms, badges on their front pockets, and severe faces appear-most likely the same facial expressions they use working the doors of nightclubs in the nearby town of Gävle. The presence of the police is as noticeable, but has a friendlier air. Several policemen and policewomen in the unit have a "Picnic Royal" before they start their shift and then patrol and seem as relaxed as the guests. County council ambulance nurses work alongside Red Cross medics to inform the public about their work and to be of assistance if anyone needs them.

Practical problems are given simple but well-thought-out solutions. A cutlery tray transforms into a picnic tray. The cake buffet table is converted into a long bench for those who have not brought a picnic blanket to sit on during the entertainment. The rhubarb syrup left over from lunch is offered as drinks for self serving. Portable loos and urinals are set up so that no one need to look far for one during their visit to Wij Gardens, and next to the stage the loos and urinals have been hidden away behind some sheaf of hay; this gives a rural impression and also function as an exciting place to climb and sit for the children; as they climb about, the stacked hay start to fall apart, and by nightfall all that remains is a flat heap of hay.

A parallel to this commercialisation of a rural identity can be found in the agrarian festivals of Provence, France. Studying the changing conceptions of the festivals, Laurent Sébastien Fournier states: "the crops from agricultural products, considered yesterday as the fruits of the common work of man and nature, have been transformed and evaluated in cultural goods." (Fournier 2006). In Ockelbo the locally produced lunch, the rhubarb syrup drinks, the wild flowers used for decorations, the stacked hay, and even the muddy stubble field, is more than agricultural products; they become symbols of cultural heritage. Linked with the shown professionalism, an image of modern rural life is presented and functions as an advertisement for village life.

\section{MUSIC AND DANCING}

A large-scale village feast finally requires entertainment and Ockelbo makes use of local, neighbouring, and nationally famous entertainers to provide this. People stroll between the entertainment points that have been strategically placed around the village: A brass band from the neighbouring town of Gävle is there early to entertain the first guests. Dressed in black vests and bowler hats the musicians perform at a crossroads near the pine walkway at Wij Gardens and, even though no one is dancing, it makes one think of rural crossroad dances of times gone by.

On a small stage built in the market square, local and regional artists and organisations entertain the passersby at lunchtime. The Lions Club present their gift to the couple: a donation to the Children's Diabetes Fund, of which the Crown Princess is guardian. Some stop to watch the entertainment, while others pop into one of the shops or share a cup of coffee with friends. 
In the village church a concert is given by the Symphony Orchestra of Gävle, directed by the promising young conductor Johan Larsson, who grew up in Ockelbo. The concert offers "classic summer hits with a love theme" and is broadcasted live on the radio (SR 2010). Not everyone finds a seat in the church, and the six hundred to seven hundred listeners that do get in nudge elbows, but fall devoutly silent when the music begins.

During the broadcast from Stockholm the entertainment on the large stage pauses, but as soon as the broadcast ends, the live entertainment resumes again. The Symphony Orchestra of Sandviken backs the artists and well-loved Swedish entertainer Lasse Berghagen acts as conférencier. The rain has started up again, but despite the dark clouds many stay to listen to the performing stars, and as a finale they come together and sing the Beatles song "All You Need is Love" and the crowd cheers so loudly it can be heard all across the county.

After the festivities at Wij Gardens and the official celebration in Ockelbo are over, one activity still remains for the locals. At Plan, the People's Amusement Park, a small funfair has set up with wagon stands and a carousel, a beer tent is open, the dance hall has been decorated with birch branches (a sign of festivities in Sweden), and a small outdoor stage is ready for the retro entertainers hired to perform that summer night. It is primarily locals that have been allowed to buy tickets to the event, and the guests arriving are in high spirits. Outside the gates, a police unit gathers for instructions, and the directive is to be lenient and only intervene if one of the 2,000 guests behaves badly or starts a fight. The real celebration can commence.

\section{REFERENCES}

British Broadcasting Corporation (BBC)

2012 Webbsite with information on the classical music festival, The BBC Proms ("http://www.bbc. co.uk/proms/" http://www.bbc.co.uk/proms/).

Dialekt- och folkminnesarkivet i Uppsala

Marlene Hugoson's documentation of the Ockelbo Celebration of the Swedish Royal Wedding on June 192010.

Fournier, Laurent Sébastien

2006 Agrarian Festivals and the Ritual Year in Mediterranean France - Preserving Traditions or Building Heritage? In: Mifsud-Chircop, George (ed.), First International Conference of the SIEF Working Group on The Ritual Year. Msida: Publishers Enterprise Group.

Gaspar, Kinga

2011 Self-Reflexivity and 'Casting' in Cultural Performances. Paper presented at the SIEF Ritual Year Conference in Ljubljana, November 122011.

Hobsbawm, Eric

2005 (1983) Mass-Producing Traditions: Europe, 1870-1914. In: Hobsbawm, Erik and Ranger, Terence (eds.), The Invention of Tradition. Cambridge: Cambridge University Press.

Hugoson, Marlene

2007 Den alternativa nobelfesten. En tv-publiks festdeltagande. In: Hugoson, Marlene (ed.), Bodil lajv. Festskrift till Bodil Nildin-Wall den 18 januari 2007. Uppsala: (Private publication). 